\title{
Pengaruh Good Corporate Governance Terhadap Agresivitas Pajak dengan Voluntary Disclosure Sebagai Variabel Pemoderasi
}

\author{
Ni Putu Pradnyawati ${ }^{1}$ \\ Herkulanus Bambang Suprasto ${ }^{2}$
}

${ }^{1,2}$ Fakultas Ekonomi dan Bisnis Universitas Udayana (Unud), Bali, Indonesia e-mail:pradnyawati5@gmail.com

\begin{abstract}
ABSTRAK
Penelitian dilakukan pada perusahaan manufaktur yang terdaftar di Bursa Efek Indonesia (BEI) periode 2015-2017. Penentuan sampel menggunakan metode non probability sampling dengan teknik purposive sampling. Teknik analisis yang digunakan adalah Moderated Regression Analysis (MRA). Berdasarkan hasil analisis ditemukan bahwa kualitas audit berpengaruh negatif terhadap agresivitas pajak. Hal tersebut menjelaskan bahwa kualitas audit mampu mengawasi tindakan agresivitas pajak. Semakin baik kualitas audit suatu perusahaan maka tindakan agresivitas pajak akan semakin rendah. Tiga pengujian lainnya tidak mampu membuktikan hipotesis yang menyatakan kepemilikan publik berpengaruh negatif terhadap agresivitas pajak, volumtary disclosure dapat memerkuat pengaruh kualitas audit terhadap agresivitas pajak, dan voluntary disclosure dapat memerkuat pengaruh kepemilikan publik terhadap agresivitas pajak.
\end{abstract}

Kata kunci: Kualitas audit, kepemilikan publik, voluntary disclosure, agresivitas pajak

\begin{abstract}
The study was conducted at manufacturing companies listed on the Indonesia Stock Exchange (IDX) for the 2015-2017 period. Determination of the sample using non probability sampling method with purposive sampling technique. The analysis technique used is Moderated Regression Analysis (MRA). Based on the results of the analysis it was found that audit quality had a negative effect on tax aggressiveness. This explains that audit quality is able to monitor the actions of tax aggressiveness. The better the audit quality of a company, the lower the tax aggressiveness. Three other tests were unable to prove the hypothesis that public ownership negatively affected tax aggressiveness, voluntary disclosure can strengthen the influence of audit quality on tax aggressiveness, and voluntary disclosure can strengthen the influence of public ownership on tax aggressiveness.
\end{abstract}

Keywords: Audit quality, public ownership, voluntary disclosure, tax aggressiveness

\section{PENDAHULUAN}

Agresivitas pajak adalah salah satu indikator yang dapat digunakan untuk melihat usaha penghindaran pajak oleh wajib pajak. Agresivitas pajak merupakan aktivitas spesifik, mencakup transaksi-transaksi yang bertujuan untuk menurunkan kewajiban pajak perusahaan (Slemrod, 2004). Menurut Frank et al. (2009) agresivitas pajak dapat dilakukan melalui mekanisme yang digolongkan tax 
Ni Putu Pradnyawati dan Herkulanus Bambang Suprasto. Pengaruh...

avoidance atau tax evasion. Tax avoidance adalah penghindaran pajak yang dilakukan perusahaan untuk mengurangi beban pajaknya dengan cara yang legal. Tax evasion adalah penggelapan pajak yang ilegal karena melanggar undangundang.

Fenomena agresivitas pajak yang terjadi yaitu terdapat beberapa perusahaan manufaktur yang menerima Surat Ketetapan Pajak Kurang Bayar (SKPKB) yang diterbitkan pada tahun 2017. SKPKB adalah surat ketetapan pajak yang menentukan besarnya jumlah pokok pajak, jumlah kredit pajak, jumlah pembayaran pokok pajak, besarnya sanksi administrasi, dan jumlah yang masih harus dibayar. Menurut Pasal 13 ayat (1) Undang-Undang KUP dalam jangka waktu lima tahun setelah saat terutangnya pajak atau berakhirnya masa pajak, bagian tahun pajak, atau tahun pajak, Direktur Jenderal Pajak (DJP) dapat menerbitkan SKPKB apabila hasil pemeriksaan pajak ditemukan pajak terutang kurang dibayar oleh wajib pajak. Perusahaan manufaktur yang menerima SKPKB yang diterbitkan pada tahun 2017 dapat dilihat pada Tabel 1 berikut.

Tabel 1.

Perusahaan Manufaktur yang Menerima SKPKB Tahun 2017

\begin{tabular}{clr}
\hline No & \multicolumn{1}{c}{ Perusahaan } & \multicolumn{1}{c}{$\begin{array}{c}\text { Kurang Bayar } \\
\text { (Rupiah) }\end{array}$} \\
\hline 1 & Arwana Citramulia Tbk. & 808.088 .257 \\
2 & Citra Tubindo Tbk. & 152.987 .400 \\
3 & Duta Pertiwi Nusantara Tbk. & 619.883 .314 \\
4 & Kalbe Farma Tbk. & 576.850 .595 \\
5 & Kirana Megatara Tbk. & 868.179 .501 \\
6 & Emdeki Utama Tbk. & 5.264 .312 .000 .000 \\
7 & Mulia Industrindo Tbk. & 1.442 .281 .000 \\
8 & Surya Toto Indonesia Tbk. & 70.894 .154 .794 \\
9 & Tirta Mahakam Resources Tbk. & 671.692 .018 \\
\hline Sumber: Data diolah, 2018
\end{tabular}

Tabel 1 menunjukkan beberapa perusahaan manufaktur yang menerima SKPKB yang diterbitkan pada tahun 2017. Perusahaan yang menerima SKPKB 
yaitu Arwana Citramulia Tbk., Citra Tubindo Tbk., Duta Pertiwi Nusantara Tbk., Kalbe Farma Tbk., Kirana Megatara Tbk., Emdeki Utama Tbk., Mulia Industrindo Tbk., Surya Toto Indonesia Tbk., dan Tirta Mahakam Resources Tbk. SKPKB diterbitkan apabila DJP menemukan pajak terutang yang kurang dibayar oleh wajib pajak. Salah satu penyebab diterbitkannya SKPKB adalah wajib pajak terindikasi melakukan tindakan agresivitas pajak, karena DJP menemukan bahwa wajib pajak tersebut kurang bayar dari pajak yang seharusnya dibayarkan.

Terdapat beberapa proksi yang dapat digunakan untuk mengukur agresivitas pajak, penelitian ini menggunakan proksi Cash Effective Tax Ratio (CETR). CETR merupakan jumlah kas yang dikeluarkan untuk membayar pajak dibagi total laba sebelum pajak. Menurut Dyreng et al. (2008) CETR baik digunakan untuk menggambarkan penghindaran pajak oleh perusahaan karena CETR tidak terpengaruh dengan adanya perubahan estimasi seperti penyisihan penilaian atau perlindungan pajak. Tabel 2 berikut ini menunjukkan CETR beberapa perusahaan manufaktur tahun 2017.

Tabel 2.

CETR Perusahaan Manufaktur Tahun 2017

\begin{tabular}{lrrr}
\hline \multicolumn{1}{c}{ Perusahaan } & $\begin{array}{c}\text { Cash Tax Paid } \\
\text { (Rupiah) }\end{array}$ & $\begin{array}{c}\text { Pre-tax Income } \\
\text { (Rupiah) }\end{array}$ & CETR \\
\hline Betonjaya Manunggal Tbk. & 14.786 .159 & 14.737 .057 .056 & 0,001 \\
Semen Baturaja (Persero) Tbk. & 5.912 .129 & 208.947 .154 & 0,028 \\
Pelangi Indah Canindo Tbk. & 852.197 .590 & 19.249 .539 .065 & 0,044 \\
Alakasa Industrindo Tbk. & 829.583 & 16.063 .389 & 0,052 \\
Mark Dynamics Indonesia Tbk. & 12.902 .849 .685 & 64.422 .123 .842 & 0,200 \\
Arwana Citramulia Tbk. & 34.886 .327 .895 & 166.203 .941 .034 & 0,210 \\
Lionmesh Prima Tbk. & $3,704,152,045$ & $17,488,236,349$ & 0,212 \\
Indal Aluminium Industry Tbk. & $12,992,559,962$ & $52,292,073,203$ & 0,248 \\
Waskita Beton Precast Tbk. & $316,810,905,504$ & $1,156,234,012,013$ & 0,274 \\
Gunawan Dianjaya Steel Tbk. & $7,678,352,301$ & $21,905,675,755$ & 0,351 \\
\hline Sumber: Data diolah, 2018 & & &
\end{tabular}


Ni Putu Pradnyawati dan Herkulanus Bambang Suprasto. Pengaruh...

Tabel 2 menunjukkan CETR beberapa perusahaan manufaktur pada tahun 2017. Kas yang dikeluarkan untuk membayar pajak pada perusahaan Betonjaya Manunggal Tbk. pada tahun 2017 yaitu Rp.14.786.159, laba sebelum pajaknya Rp.14.737.057.056, sehingga CETRnya 0,001. CETR 0,001 mencerminkan bahwa kas yang dikeluarkan untuk membayar pajak perusahaan ini hanya 0,1 persen dari laba sebelum pajak. Pada perusahaan Semen Baturaja (Persero) Tbk., Pelangi Indah Carindo Tbk., Alakasa Industrindo Tbk., Mark Dynamics Indonesia Tbk., Arwana Citramulia Tbk., Lionmesh Prima Tbk., Indal Aluminium Industry Tbk., Waskita Beton Precast Tbk., dan Gunawan Dianjaya Steel Tbk. memiliki CETR masing-masing sebesar 0,$028 ; 0,044 ; 0,052 ; 0,200 ; 0,210 ; 0,212 ; 0,248$; 0,274; dan 0,351. Perbedaan nilai CETR menunjukkan perbedaan kas yang dikeluarkan untuk membayar pajak perusahaan. Perbedaan milai CETR dengan tarif pajak yang sesungguhnya mengindikasikan adanya agresivitas pajak. Semakin tinggi CETR mencerminkan semakin rendahnya tingkat agresivitas pajak. Sebaliknya bila semakin rendah CETR, maka tingkat agresivitas pajak semakin tinggi.

Penelitian tentang agresivitas pajak telah banyak dilakukan oleh beberapa peneliti. Variabel yang telah diteliti yang memengaruhi agresivitas pajak antara lain Corporate Governance (CG), Corporate Social Responsibility (CSR), kualitas audit, struktur kepemilikan, karakteristik dewan, leverage, likuiditas, ukuran perusahaan, dan beberapa variabel lainnya. Suprimarini dan Suprasto (2017) meneliti tentang pengaruh CSR, kualitas audit, dan kepemilikan institusional pada agresivitas pajak. Dewi dan Noviari (2017) meneliti tentang 
pengaruh ukuran perusahaan, leverage, profitabilitas, dan CSR terhadap penghindaran pajak. Mangoting dan Hadi (2014) meneliti mengenai pengaruh struktur kepemilikan dan karakteristik dewan terhadap agresivitas pajak.

Penelitian Suprimarini dan Suprasto (2017) menyatakan bahwa CSR berpengaruh negatif signifikan terhadap agresivitas pajak, kualitas audit berpengaruh positif signifikan terhadap agresivitas pajak, dan kepemilikan institusional tidak berpengaruh terhadap agresivitas pajak. Hasil penelitian Dewi dan Noviari (2017) yaitu ukuran perusahaan, leverage, dan pengungkapan CSR berpengaruh negatif dan signifikan pada penghindaran pajak, sedangkan profitabilitas berpengaruh positif dan signifikan terhadap penghindaran pajak. Mangoting dan Hadi (2014) menunjukkan hasil bahwa struktur kepemilikan berpengaruh signifikan terhadap agresivitas pajak, sedangkan karakteristik dewan tidak berpengaruh terhadap agresivitas pajak.

Menurut Kementrian BUMN berdasarkan pasal 1 ayat 1 Peraturan Menteri Negara BUMN No.PER-01/MBU/2011 Good Corporate Governance (GCG) adalah prinsip-prinsip yang mendasari suatu proses dan mekanisme pengelolaan perusahaan berlandaskan peraturan perundang-undangan. Terdapat tujuh fungsi penting dari GCG yaitu pengaturan, manajemen, kepatuhan, audit internal, pengarah, audit eksternal, dan pengawasan. Peran GCG dapat mendorong kepatuhan perusahaan sebagai wajib pajak untuk menjalankan kewajiban perpajakannya. GCG dapat berperan dalam manajemen pajak jangka panjang (Minnick \& Noga, 2010). Menurut Friese et al. (2006) pemenuhan kewajiban perpajakan dalam perusahaan dipengaruhi oleh budaya dan dinamika sistem tata 
Ni Putu Pradnyawati dan Herkulanus Bambang Suprasto. Pengaruh...

kelola perusahaan. Penerapan GCG diharapkan dapat menciptakan pengawasan terhadap kegiatan manajer sehingga dapat meminimalisasi tindakan agresivitas pajak yang dilakukan oleh perusahaan. Oleh karena itu, GCG sangat berkaitan dengan pemerintah dalam hal pemenuhan kewajiban perpajakan perusahaan.

Sebuah perusahaan dikategorikan telah menerapkan GCG apabila prinsipprinsip pokok GCG yang terdiri dari transparansi, akuntabilitas, responsibilitas, independensi, serta kewajaran dan kesetaraan dijalankan dalam perusahaan dengan baik. Prinsip-prinsip tersebut dapat diterapkan melalui mekanisme GCG. Mekanisme GCG dibagi menjadi dua yaitu mekanisme internal dan mekanisme eksternal. Menurut Sutedi (2012) mekanisme internal terdiri dari manajer, dewan direksi, dewan komisaris, karyawan, sistem remunerasi, dan komite audit perusahaan. Mekanisme eksternal terdiri dari kecukupan undang-undang dan perangkat hukum, investor, institut penyedia informasi, akuntan publik, institut yang memihak kepentingan publik bukan golongan, pemberi pinjaman, dan lembaga yang mengesahkan legalitas. Mekanisme GCG pada penelitian ini diproksikan dengan kualitas audit dan kepemilikan publik.

Penelitian yang telah dilakukan mengenai pengaruh GCG terhadap agresivitas pajak kebanyakan hanya meneliti mekanisme kontrol internal. Sedangkan penelitian dengan melibatkan mekanisme kontrol eksternal seperti kualitas audit dan kepemilikan publik belum banyak diteliti (Aguilera et al., 2015). Keberadaan auditor eksternal dan pemegang saham publik dapat mengawasi perkembangan perusahaan yang menyebabkan tingkat pengendalian terhadap tindakan manajemen lebih baik sehingga potensi penghindaran pajak 
dapat diminimalisasi. Oleh karena itu, penulis meneliti tentang pengaruh kualitas audit dan kepemilikan publik terhadap agresivitas pajak.

DeAngelo (1981) mendifinisikan kualitas audit sebagai suatu probabilitas dimana seorang auditor dapat menemukan serta melaporkan tentang adanya suatu pelanggaran dalam sistem akuntansi klien. Kualitas audit diproksikan dengan ukuran Kantor Akuntan Publik (KAP), apakah KAP tersebut termasuk kedalam KAP Big Four atau tidak. Tindakan agresivitas pajak lebih sulit dilakukan pada perusahaan yang diaudit oleh KAP Big Four karena auditor pada KAP Big Four akan bekerja optimal untuk mempertahankan reputasinya, lebih transparan, dan mampu menjaga integritasnya dalam pelaksanaan audit.

Penelitian yang dilakukan oleh Indrawan (2016), Maharani dan Suardana (2014), Dewi dan Jati (2014), Annisa dan Kurniasih (2012) yang menunjukkan hasil bahwa kualitas audit berpengaruh negatif terhadap penghindaran pajak. Namun Eksandy (2014), Suprimarini dan Suprasto (2017) menunjukkan hasil penelitian bahwa kualitas audit berpengaruh positif terhadap penghindaran pajak. Selain itu Hidayati dan Fidiana (2017), Alviyani (2016), dan Winata (2014) menyimpulkan bahwa kualitas audit tidak berpengaruh terhadap penghindaran pajak.

Pemegang saham publik merupakan pemegang saham dengan kekuatan minoritas dalam perusahaan. Adanya kepentingan pemegang saham dalam perusahaan tampaknya memengaruhi kecendrungan penghindaran pajak perusahaan Core et al. (1999). Kepemilikan saham publik merupakan salah satu mekanisme yang dapat digunakan untuk meningkatkan efektivitas monitoring. 
Ni Putu Pradnyawati dan Herkulanus Bambang Suprasto. Pengaruh...

Pemegang saham publik akan mengawasi operasi perusahaan agar tidak melakukan hal-hal yang menyimpang dari aturan.

Puspita dan Harto (2014) menemukan hubungan negatif antara kepemilikan publik dengan penghindaran pajak. Atiah et al. (2016) dan Prayogo dan Darsono (2015) yang menemukan bahwa kepemilikan publik berperan sebagai penghambat manajemen laba dalam mengurangi penghasilan. Manajemen laba yang didukung oleh publik adalah yang menaikkan penghasilan agar memenuhi harapan dan meningkatkan harga saham. Namun hal ini berbeda dengan penelitian yang dilakukan oleh Santoso dan Muid (2014) yang menunjukkan bahwa kepemilikan publik tidak berpengaruh signifikan terhadap agresivitas pajak dan Oktaviana (2017) yang menunjukkan kepemilikan publik berpengaruh positif terhadap agresivitas pajak.

Dilihat dari penelitian terdahulu dapat disimpulkan bahwa pengaruh kualitas audit dan kepemilikan publik terhadap agresivitas pajak masih menunjukkan hasil yang tidak konsisten. Hal ini menimbulkan keinginan peneliti untuk mengetahui apakah ada variabel yang mampu memoderasi pengaruh kualitas audit dan kepemilikan publik terhadap agresivitas pajak. Variabel yang dipilih penulis yaitu voluntary disclosure.

Menurut Meek et al. (1995) voluntary disclosure merupakan pengungkapan melebihi dari yang diharuskan oleh peraturan. Amalia (2005) menyatakan bahwa pengungkapan informasi non-finansial sangat penting bagi stakeholders karena adanya keterbatasan pengukuran finansial. Informasi yang terdapat pada pengungkapan sukarela dinilai dapat memberikan gambaran dalam 
menjelaskan resiko yang mungkin dapat diminimalisir. Semakin banyak pengungkapan sukarela yang dilakukan perusahaan, maka semakin banyak informasi yang diperoleh KAP dan pemegang saham publik untuk memberikan gambaran dalam menjelaskan resiko yang mungkin dapat diminimalisir. Gambaran yang menjelaskan resiko perusahaan dapat dijadikan kontrol atas kewajiban-kewajiban perusahaan, salah satunya yaitu kewajiban perpajakan. Oleh sebab itu peneliti ingin menguji peran voluntary disclosure dalam memperkuat hubungan antara kualitas audit dan kepemilikan publik dengan agresivitas pajak.

Penelitian ini difokuskan pada perusahaan manufaktur yang terdaftar di Bursa Efek Indonesia periode 2015-2017. Peneliti memilih perusahaan manufaktur karena mengacu pada data United Nations Statistics Division pada tahun 2016, Indonesia menempati peringkat keempat dunia dari 15 negara yang industri manufakturnya memberikan kontribusi signifikan terhadap Produk Domestik Bruto (PDB). Selain itu, terdapat 160 perusahaan manufaktur dari 557 perusahaan yang terdaftar di Bursa Efek Indonesia per Desember 2017. Jumlah perusahaan manufaktur mencapai lebih dari 25 persen dari total perusahaan yang terdaftar di BEI sehingga prilaku pajak agresif pada industri manufaktur akan berpengaruh cukup signifikan terhadap penerimaan negara dari sektor pajak.

Rosnidah (2010) menyatakan kualitas audit merupakan pelaksanaan audit yang dilakukan sesuai standar sehingga auditor mampu mengungkapkan dan melaporkan apabila terjadi pelanggaran yang dilakukan klien. Ikatan Akuntan Indonesia (IAI) menyatakan audit yang dilakukan berkualitas jika memenuhi standar auditing dan standar pengendalian mutu. Theory of Planned Behavior 
Ni Putu Pradnyawati dan Herkulanus Bambang Suprasto. Pengaruh...

menjelaskan bahwa perilaku individu terhadap perilaku tertentu diakibatkan oleh niat seorang individu. Niat tersebut muncul dari beberapa faktor, salah satunya yaitu kontrol keperilakukan. Audit berkualitas dapat menimbulkan kontrol yang mempersulit perilaku agresivitas pajak yang ditunjukkan melalui nilai CETR perusahaan yang tinggi. Hal ini terjadi karena audit berkualitas dapat mengurangi resiko yang mungkin dilakukan oleh dewan dengan keputusan-keputusan yang menguntungkan diri sendiri.

Penelitian sebelumnya yang dilakukan oleh Maharani dan Suardana (2014) menemukan bahwa kualitas audit berpengaruh negatif terhadap tax avoidance. Hasil penelitian Annisa dan Kurniasih (2012), Dewi dan Jati (2014), serta Indrawan (2016) juga menunjukkan hasil serupa, bahwa kualitas audit memiliki pengaruh negatif terhadap penghindaran pajak.

KAP Big Four sejalan dengan kualitas audit dijelaskan melalui dua hal. Pertama, KAP Big Four yang berskala internasional memiliki sumber daya partner yang menjadi keunggulan bagi KAP dalam menguasai teknik audit dan pemahaman bisnis klien. Kedua, besarnya KAP menunjukkan besarnya segmen pasar yang melakukan kontrak dengan KAP. Besarnya nilai kontrak KAP Big Four sebanding dengan risiko reputasi yang akan dihadapi oleh KAP Big Four. Hal tersebut mendorong partner untuk saling mengawasi sehingga meningkatkan independensi dan kompetensi partner lain. Tindakan agresivitas pajak lebih sulit dilakukan pada perusahaan yang diaudit oleh KAP Big Four karena auditor pada KAP Big Four akan bekerja optimal untuk mempertahankan reputasinya, lebih transparan, dan mampu menjaga integritasnya dalam pelaksanaan audit. 
Berdasarkan uraian diatas maka dapat dirumuskan hipotesis penelitian sebagai berikut:

$\mathrm{H}_{1}$ : Kualitas audit berpengaruh negatif terhadap agresivitas pajak.

Kepemilikan publik merupakan kepemilikan saham perusahaan oleh masyarakat yang nilai kepemilikannya masing-masing kurang dari 5\%. Peran kepemilikan publik dalam perusahaan diungkapkan oleh Vander Bauwhede et al. (2003) yang menemukan bahwa kepemilikan publik berperan sebagai penghambat manajemen laba dalam mengurangi penghasilan. Theory of Planned Behavior menjelaskan bahwa perilaku individu terhadap perilaku tertentu diakibatkan oleh niat seorang individu. Niat tersebut muncul dari beberapa faktor, salah satunya yaitu kontrol keperilakukan. Adanya kepentingan pemegang saham dalam perusahaan tampaknya memengaruhi kecendrungan penghindaran pajak perusahaan (Core et al., 1999). Proporsi kepemilikan saham publik dapat menimbulkan kontrol yang mempersulit perilaku agresivitas pajak yang ditunjukkan melalui nilai CETR perusahaan yang tinggi karena pemegang saham publik memiliki kepentingan pada perusahaan sehingga pemegang saham publik akan mengawasi operasi perusahaan agar tidak melakukan hal-hal yang menyimpang dari aturan.

Studi tentang pengaruh kepemilikan publik terhadap agresivitas pajak yang dilaksanakan oleh Puspita dan Harto (2014) menemukan hubungan negatif antara kepemilikan publik dengan penghindaran pajak. Hasil penelitian Atiah et al. (2016) juga menunjukkan hasil serupa, bahwa kepemilikan publik berperan sebagai penghambat manajemen laba dalam mengurangi penghasilan. Namun 
Ni Putu Pradnyawati dan Herkulanus Bambang Suprasto. Pengaruh...

penelitian Prayogo dan Darsono (2015) menyatakan kepemilikan saham publik tidak berpengaruh terhadap penghindaran pajak.

Kepemilikan saham publik merupakan salah satu mekanisme yang dapat digunakan untuk meningkatkan efektivitas monitoring. Pemegang saham publik akan mengawasi operasi perusahaan agar tidak melakukan hal-hal yang menyimpang dari aturan. Semakin besar kepemilikan saham oleh masyarakat maka semakin besar pengawasan yang dilakukan pemegang saham terhadap perusahaan, sehingga perusahaan lebih sulit melakukan agresivitas pajak. Selain itu, pemegang saham publik memiliki karakteristik seperti masyarakat pada umumnya, yang mengharapkan perusahaan memberikan kontribusi untuk pembangunan dalam bentuk pembayaran pajak. Berdasarkan uraian diatas maka dapat dirumuskan hipotesis penelitian sebagai berikut:

$\mathrm{H}_{2}$ : Kepemilikan publik berpengaruh negatif terhadap agresivitas pajak.

Menurut Meek et al. (1995) voluntary disclosure merupakan pengungkapan yang melebihi dari yang diharuskan oleh peraturan. Pengungkapan sukarela merupakan pengungkapan butir-butir yang dilakukan secara sukarela oleh perusahaan tanpa diharuskan oleh peraturan yang berlaku (Amalia, 2005). Pengungkapan ini meliputi gambaran strategi perusahaan dalam jangka panjang, indikator-indikator non-finansial penting yang berfungsi untuk keefektivitasan implementasi strategi perusahaan dan bermanfaat dalam menjelaskan hubungan antara indikator-indikator penting tersebut dengan laba yang akan datang (Healy dan Palepu, 1993). Teori sinyal menjelaskan bagaimana pihak manajemen perusahaan memberikan informasi, sehingga dapat memberikan informasi 
mengenai keadaan serta prospek perusahaan. Voluntary disclosure yang terdapat pada laporan tahunan merupakan salah satu informasi yang bisa digunakan sebagai sinyal bagi auditor dalam mengawasi tindakan agresivitas perusahaan.

Menurut Partha dan Noviari (2016) voluntary disclosure dapat mengurangi risiko deteksi kebijakan penghindaran pajak dan asimetri informasi. Voluntary disclosure merupakan wujud dari transparansi. Transparansi menjadi elemen penting dalam kualitas audit. Peningkatan transparansi dalam hal pajak semakin dituntut oleh publik. Dengan adanya transparasi dapat memperluas cakupan pemeriksaan audit. Dengan semakin luasnya pemeriksaan audit, maka auditor dapat lebih mudah menemukan adanya tingkat kecurangan dalam penghindaran pajak. Maka dari itu, dengan adanya voluntary disclosure akan meminimalisir agresivitas pajak karena ruang lingkup pemeriksaan audit akan lebih luas dengan adanya voluntary disclosure. Berdasarkan uraian diatas maka dapat dirumuskan hipotesis sebagai berikut:

$\mathrm{H}_{3}$ : Voluntary disclosure dapat memerkuat pengaruh kualitas audit terhadap agresivitas pajak.

Investor sebagai pemegang saham publik suatu perusahaan tentunya membutuhkan informasi seluas-luasnya yang digunakan sebagai acuan dalam pengambilan keputusan. Perusahaan melakukan pengungkapan yang lebih luas dari pengungkapan yang diwajibkan dengan melakukan voluntary disclosure. Menurut Meek et al. (1995) voluntary disclosure merupakan pengungkapan yang melebihi dari yang diharuskan oleh peraturan. Pengungkapan sukarela merupakan pengungkapan butir-butir yang dilakukan secara sukarela oleh perusahaan tanpa diharuskan oleh peraturan yang berlaku (Amalia, 2005). Informasi yang terdapat 
Ni Putu Pradnyawati dan Herkulanus Bambang Suprasto. Pengaruh...

pada pengungkapan sukarela dinilai dapat memberikan gambaran dalam menjelaskan resiko yang mungkin dapat diminimalisir. Teori sinyal menjelaskan bagaimana pihak manajemen perusahaan memberikan informasi, sehingga dapat memberikan informasi mengenai keadaan serta prospek perusahaan. Voluntary disclosure yang terdapat pada laporan tahunan merupakan salah satu informasi yang bisa digunakan sebagai sinyal bagi pemegang saham publik dalam mengawasi tindakan agresivitas perusahaan.

Voluntary disclosure membuat perusahaan lebih transparan bagi investor. Transparansi yang dilakukan oleh perusahaan dapat menghindarkan perusahaan dalam melakukan tindakan agresif pada kewajiban perpajakannya. Semakin transparan suatu perusahaan maka semakin kecil kemungkinan terjadinya pelanggaran pajak, sebab masyarakat dalam hal ini pemegang saham publik dapat berperan sebagai kontrol atas kewajiban-kewajiban perusahaan. Voluntary disclosure akan meminimalisir terjadinya agresivitas pajak karena semakin banyak pengungkapan informasi perusahaan maka semakin tinggi kontrol masyarakat dalam mengawasi penghindaran terhadap pajak. Berdasarkan uraian diatas maka dapat dirumuskan hipotesis penelitian sebagai berikut:

$\mathrm{H}_{4}$ : Voluntary disclosure dapat memerkuat pengaruh kepemilikan publik terhadap agresivitas pajak

\section{METODE PENELITIAN}

Penelitian ini berlokasi di Bursa Efek Indonesia (BEI). Objek penelitian yang digunakan dalam penelitian ini adalah agresivitas pajak pada perusahaanperusahaan manufaktur yang terdaftar di BEI, untuk mengetahui pengaruh Good 
Corporate Governance (GCG) terhadap agresivitas pajak dengan voluntary disclosure sebagai variabel pemoderasinya. Metode yang digunakan untuk pengambilan sampel adalah metode non-probability sampling dengan teknik purposive sampling. Desain penelitian ini dapat digambarkan sebagai berikut.

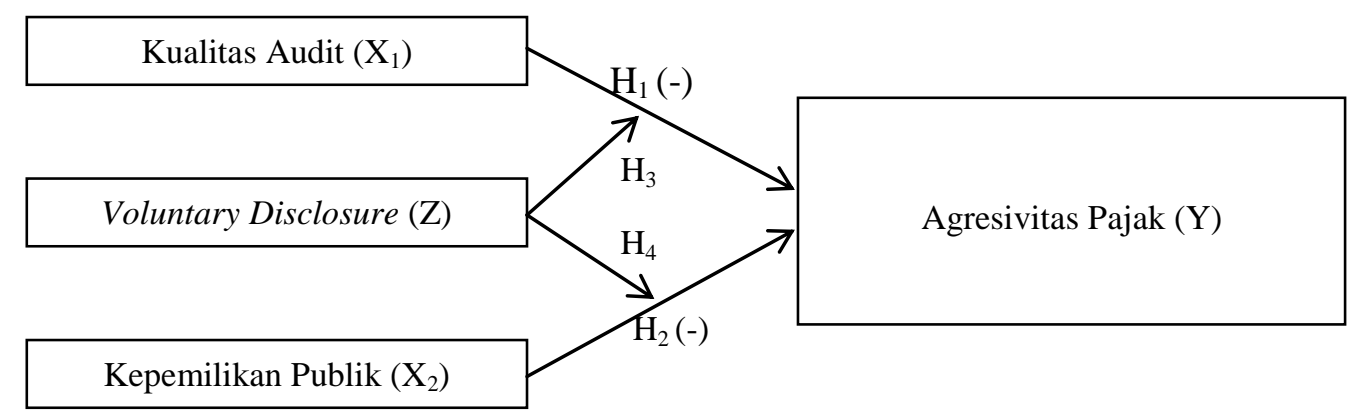

Sumber: Data diolah, 2017

\section{Gambar 1. Desain Penelitian}

Kualitas audit diukur dengan menggunakan variable dummy yang bernilai 0 apabila audit laporan keuangan tidak dilakukan oleh Kantor Akuntan Publik (KAP) The Big Four dan bernilai 1 apabila audit laporan keuangan dilakukan oleh Kantor Akuntan Publik (KAP) The Big Four yang terdiri atas: (1) PWC, (2) EY, (3) Delliote, dan (4) KPMG. Kepemilikan saham publik diukur melalui rasio dari jumlah kepemilikan lembar saham yang dimiliki publik terhadap jumlah saham yang beredar. Berikut merupakan model perhitungannya.

Kepemilikan Publik $=\frac{\text { Jumlah saham kepemilikan publik }}{\text { Jumlah saham yang beredar }}$

Agresivitas pajak pada penelitian ini diukur dengan Cash Effective Tax Rate (CETR). CETR menggunakan model yang dikembangkan oleh Dyreng et al. (2008) yaitu sebagai berikut: 
Ni Putu Pradnyawati dan Herkulanus Bambang Suprasto. Pengaruh...

CETR $=\frac{\text { Cash Tax Paid }}{\text { Pre-tax Income }} \ldots \ldots \ldots \ldots \ldots \ldots \ldots \ldots \ldots \ldots \ldots \ldots \ldots \ldots \ldots \ldots \ldots \ldots \ldots \ldots \ldots \ldots \ldots$
Voluntary disclosure dalam penelitian ini menggunakan daftar item pengungkapan dari penelitian Wulandari dan Laksito (2015) yang mengacu pada penelitian Sehar dan Tufail (2013) dan telah disesuaikan dengan Keputusan Ketua Bapepam-LK No. KEP-431/BL/2012 Tentang Penyampaian Laporan Tahunan Emiten atau Perusahaan Publik.

Teknik analisis yang digunakan pada penelitian ini adalah Uji Moderated Regression Analysis (MRA). Adapun model persamaan MRA dalam penelitian ini dinyatakan sebagai berikut.

$Y=\alpha+\beta_{1} X_{1}+\beta_{2} X_{2}+\beta_{3} Z+\beta_{4} X_{1} Z+\beta_{5} X_{2} Z+\varepsilon$

Keterangan:

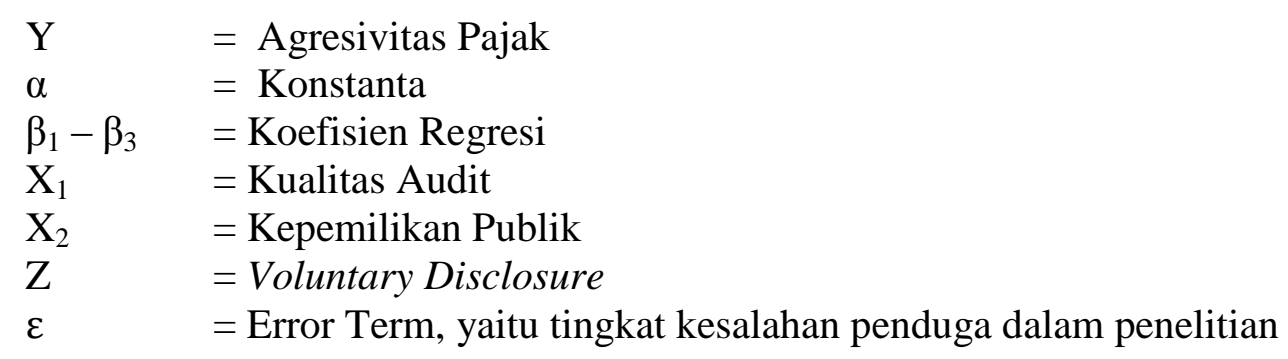

\section{HASIL DAN PEMBAHASAN}

Berdasarkan kriteria pemilihan sampel yang digunakan, maka perusahaan yang memenuhi kriteria adalah sebanyak 39 perusahaan dengan proses penyeleksian pada Tabel 3 berikut. 
Tabel 3.

Penentuan Jumlah Sampel

\begin{tabular}{clc}
\hline No & \multicolumn{1}{c}{ Kriteria Sampel } & Jumlah \\
\hline 1 & $\begin{array}{l}\text { Perusahaan manufaktur yang terdaftar di Bursa Efek Indonesia dari } \\
\text { tahun 2015-2017. }\end{array}$ & 160 \\
2 & $\begin{array}{l}\text { Perusahaan manufaktur yang tidak berturut-turut terdaftar di Bursa } \\
\text { Efek Indonesia selama periode 2015-2017. }\end{array}$ \\
3 & $\begin{array}{l}\text { Perusahaan manufaktur yang tidak mempublikasikan laporan tahunan } \\
\text { secara lengkap dalam bentuk denominasi rupiah (IDR) berturut-turut }\end{array}$ \\
& selama tahun 2015-2017 dan tidak memuat data-data atau informasi \\
$\quad$ yang digunakan dalam penelitian ini. & \\
& $\begin{array}{l}\text { Perusahaan manufaktur yang mengalami kerugian pada periode 2015- } \\
\text { 2017. }\end{array}$ \\
Jumlah sampel & \\
Jumlah pengamatan penelitian (3 tahun) & 38 \\
Sumber: Data diolah, 2018 & 114
\end{tabular}

Berdasarkan hasil penelitian yang dilaksanakan dapat dijelaskan gambaran deskriptif mengenai karakteristik perusahaan yang meliputi agresivitas pajak, kualitas audit, kepemilikan publik, dan voluntary disclosure. Statistik deskriptif dari variabel-variabel yang digunakan dalam penelitian ini dapat dilihat melalui Tabel 4 berikut.

Tabel 4.

Statistik Deskriptif Variabel Penelitian

\begin{tabular}{lllllc}
\hline \multicolumn{1}{c}{ Variabel } & N & \multicolumn{1}{c}{ Min. } & \multicolumn{1}{c}{ Max. } & \multicolumn{1}{c}{ Mean } & $\begin{array}{c}\text { Std. } \\
\text { Deviation }\end{array}$ \\
\hline Agresivitas Pajak (Y) & 114 & 0,000 & 0,476 & 0,26798 & 0,098 \\
Kualitas Audit $\left(\mathrm{X}_{1}\right)$ & 114 & 0 & 1 & 0,53 & 0,502 \\
Kepemilikan Publik $\left(\mathrm{X}_{2}\right)$ & 114 & 0,006 & 0,520 & 0,25011 & 0,144 \\
Voluntary Disclosure $(\mathrm{Z})$ & 114 & 0,182 & 0,515 & 0,35274 & 0,076 \\
\hline Sumber: Data & & &
\end{tabular}

Sumber: Data diolah, 2018

Agresivitas pajak merupakan aktivitas spesifik, mencakup transaksitransaksi yang bertujuan untuk menurunkan kewajiban pajak perusahaan (Slemrod, 2004). Agresivitas pajak pada penelitian ini diproksikan dengan CETR yang diukur dengan perbandingan antara kas yang dikeluarkan untuk membayar pajak dan laba sebelum pajak. Semakin tinggi nilai CETR mencerminkan semakin rendahnya tingkat agresivitas pajak dan sebaliknya. Berdasarkan hasil uji statistik deskriptif, diperoleh nilai minimum CETR sebesar 0,0003 pada ULTJ tahun 2017. 
Ni Putu Pradnyawati dan Herkulanus Bambang Suprasto. Pengaruh...

Nilai CETR sebesar 0,0003 menunjukkan bahwa kas yang dibayarkan perusahaan hanya 0,03 persen dari laba sebelum pajaknya. Hal ini menunjukkan adanya agresivitas pajak karena nilai CETR jauh lebih kecil dari tarif pajak sesungguhnya. Nilai maksimum sebesar 0,476 pada AUTO tahun 2015. Variabel agresivitas pajak memiliki nilai rata-rata sebesar 0,26798. Hal ini menunjukkan bahwa rata-rata perusahaan yang dijadikan sampel membayar pajak sebesar $26,798 \%$ dari laba sebelum pajak perusahaan. Rata-rata pembayaran pajak perusahaan yang sudah cukup tinggi ini menunjukkan tindakan agresivitas pajak yang dilakukan perusahaan masih tergolong rendah. Standar deviasi agresivitas pajak sebesar 0,098 nilai ini lebih rendah dibandingkan dengan nilai rata-rata, hal ini menunjukkan bahwa sebaran data agresivitas pajak sudah merata dan cenderung homogen karena nilai standar deviasi mendekati nol.

Kualitas audit diukur dengan menggunakan variable dummy yang bernilai 0 apabila audit laporan keuangan tidak dilakukan oleh KAP Big Four dan bernilai 1 apabila audit laporan keuangan dilakukan oleh KAP Big Four. Variabel kualitas audit memiliki nilai minimum sebesar 0 pada perusahaan yang tidak diaudit oleh KAP Big Four dan nilai maksimum sebesar 1 pada perusahaan yang diaudit oleh KAP Big Four. Variabel kualitas audit memiliki nilai rata-rata sebesar 0,53 dimana nilai tersebut mendekati nilai maksimum yang artinya perusahaan yang dijadikan sampel lebih banyak diaudit oleh KAP Big Four. Standar deviasi kualitas audit yaitu 0,502 nilai ini lebih rendah dibandingkan dengan nilai rata-rata, hal ini menunjukkan bahwa sebaran data kualitas audit sudah merata dan cenderung homogen karena nilai standar deviasi mendekati nol. 
Kepemilikan publik diukur berdasarkan proporsi kepemilikan saham oleh publik dibandingkan dengan total jumlah saham yang beredar. Berdasarkan hasil uji statistik deskriptif, diperoleh nilai minimum kepemilikan publik sebesar 0,006 pada TALF tahun 2017 dan nilai maksimum sebesar 0,520 pada RICY tahun 2015. Variabel kepemilikan publik memiliki nilai rata-rata sebesar 0,25011 yang menunjukkan rata-rata publik memiliki 25,01 persen saham dari seluruh saham perusahaan yang dijadikan sampel. Standar deviasi sebesar 0,144 nilai ini lebih rendah dibandingkan dengan nilai rata-rata, hal ini menunjukkan bahwa sebaran data kepemilikan publik sudah merata dan cenderung homogen karena nilai standar deviasi mendekati nol.

Voluntary disclosure diukur dengan menggunakan luas pengungkapan sukarela yang berdasarkan pada indeks pengungkapan sukarela. Berdasarkan hasil uji statistik deskriptif, diperoleh nilai minimum sebesar 0,182 pada PICO dan BATA tahun 2015. Nilai maksimum sebesar 0,515 pada AUTO tahun 2017 dan nilai rata-rata sebesar 0,35274 . Standar deviasi sebesar 0,076 nilai ini lebih rendah dibandingkan dengan nilai rata-rata, hal ini menunjukkan bahwa sebaran data voluntary disclosure sudah merata dan cenderung homogen karena nilai standar deviasi mendekati nol.

Uji MRA yang merupakan suatu uji yang dilakukan untuk mengetahui apakah variabel voluntary disclosure mampu memoderasi hubungan kualitas audit dan kepemilikan publik terhadap agresivitas pajak. Hasil pengujian MRA disajikan pada Tabel 5 berikut. 
Ni Putu Pradnyawati dan Herkulanus Bambang Suprasto. Pengaruh...

Tabel 5.

Hasil Uji Moderated Regression Analysis

\begin{tabular}{|c|c|c|c|}
\hline \multirow{2}{*}{ Model } & \multicolumn{2}{|c|}{ Unstandardized Coefficients } & \multirow{2}{*}{ Sig. } \\
\hline & B & Std. Error & \\
\hline (Constant) & 0,032 & 0,084 & 0,705 \\
\hline Kualitas Audit $\left(\mathrm{X}_{1}\right)$ & 0,187 & 0,087 & 0,034 \\
\hline Kepemilikan Publik $\left(\mathrm{X}_{2}\right)$ & 0,239 & 0,317 & 0,452 \\
\hline Voluntary Disclosure (Z) & 0,532 & 0,229 & 0,022 \\
\hline Interaksi $1\left(\mathrm{X}_{1} \mathrm{Z}\right)$ & $-0,487$ & 0,244 & 0,048 \\
\hline Interaksi $2\left(\mathrm{X}_{2} \mathrm{Z}\right)$ & $-0,200$ & 0,875 & 0,819 \\
\hline Adjusted $R$ Square & 0,100 & & \\
\hline $\mathrm{F}$ & 3,508 & & \\
\hline F Sig. & 0,006 & & \\
\hline
\end{tabular}

Sumber: Data diolah, 2018

Persamaan regresi yang dihasilkan melalui Moderated Regression Analysis adalah sebagai berikut.

$$
Y=0,032+0,187 X_{1}+0,239 X_{2}+0,532 Z-0,487 X_{1} Z-0,200 X_{2} Z+\varepsilon
$$

Tabel 5 menunjukkan nilai adjusted $\mathrm{R}^{2}$ sebesar 0,100 yang berarti $10 \%$ variasi agresivitas pajak dapat dijelaskan oleh variasi dari kualitas audit, kepemilikan publik, dan voluntary disclosure, sedangkan sebesar 90\% dapat dijelaskan oleh variabel-variabel lain di luar variabel penelitian. Nilai F hitung sebesar 3,508 dengan tingkat signifikansi sebesar $0,006<0,05$. Hasil tersebut menunjukkan bahwa variabel - variabel independen beserta interaksinya berpengaruh terhadap variabel dependennya yaitu agresivitas pajak. Berdasarkan hasil tersebut maka dapat disimpulkan bahwa model penelitian ini dikatakan layak digunakan untuk menjelaskan pengaruh variabel-variabel bebas terhadap variabel terikat.

Hipotesis 1 pada penelitian ini yaitu kualitas audit berpengaruh negatif terhadap agresivitas pajak. Agresivitas pajak pada penelitian ini diproksikan dengan CETR yang diukur dengan perbandingan antara kas yang dikeluarkan untuk membayar pajak dan laba sebelum pajak. Semakin tinggi nilai CETR 
mencerminkan semakin rendahnya tingkat agresivitas pajak dan sebaliknya. Berdasarkan Tabel 5 hasil uji statistik $\mathrm{t}$ menunjukkan bahwa kualitas audit memiliki nilai koefisien sebesar 0,187 dengan nilai $p$-value sebesar $0,034<0,05$ yang berarti variabel kualitas audit mempunyai pengaruh terhadap CETR sebagai proksi agresivitas pajak. Nilai koefisien regresi $\beta_{1}$ sebesar 0,187 menunjukkan hubungan positif antara kualitas audit dengan CETR. Semakin tinggi kualitas audit perusahaan maka CETR perusahaan juga akan meningkat. Dengan demikian hasil pengujian tersebut menunjukkan bahwa kualitas audit berpengaruh negatif terhadap agresivitas pajak. Artinya, semakin baik kualitas audit maka semakin rendah tingkat agresivitas pajak perusahaan, begitu pula sebaliknya apabila kualitas audit semakin buruk maka tingkat agresivitas pajak akan meningkat, sehingga hipotesis 1 diterima.

Hasil penelitian ini mendukung Theory of Planned Behavior yang menjelaskan bahwa perilaku individu terhadap perilaku tertentu diakibatkan oleh niat seorang individu. Niat tersebut muncul dari beberapa faktor, salah satunya yaitu kontrol keperilakuan. Kualitas audit dapat menimbulkan kontrol terhadap perilaku agresivitas pajak karena kualitas audit merupakan pelaksanaan audit yang dilakukan sesuai standar sehingga auditor mampu mengungkapkan dan melaporkan apabila terjadi pelanggaran yang dilakukan klien.

Hasil penelitian ini konsisten dengan penelitian dari Indrawan (2016), Dewi dan Jati (2014), serta Annisa dan Kurniasih (2012) yang menyatakan bahwa kualitas audit berpengaruh negatif terhadap agresivitas pajak. Hal ini disebabkan karena kualitas audit yang baik dapat menemukan pelanggaran atau kesalahan 
Ni Putu Pradnyawati dan Herkulanus Bambang Suprasto. Pengaruh...

yang terjadi dan melaporkannya dalam laporan keuangan. Kualitas audit yang baik juga memiliki pengetahuan yang lebih luas tentang cara mendeteksi kecurangan yang mungkin dilakukan oleh perusahaan termasuk kecurangan dalam melakukan penghindaran pajak sehingga manajemen perusahaan takut melakukan tindakan agresivitas pajak. Selain itu, auditor yang berkualitas baik tidak akan menghendaki manajemen perusahaan kliennya melakukan tindakan agresivitas pajak yang dapat mengurangi pendapatan negara. Apabila perusahaan yang melakukan agresivitas pajak diketahui oleh aparat pajak maka auditor juga akan menerima risiko khususnya risiko reputasi.

Hipotesis 2 pada penelitian ini adalah kepemilikan publik berpengaruh negatif terhadap agresivitas pajak. Hasil yang diperoleh dari uji statistik t pada Tabel 4.6 menunjukkan bahwa kepemilikan publik memiliki nilai koefisien sebesar 0,239 dengan nilai $p$-value sebesar 0,452>0,05 yang berarti variabel kepemilikan publik tidak berpengaruh terhadap CETR. Artinya, semakin tinggi maupun rendah tingkat kepemilikan publik tidak akan berpengaruh terhadap agresivitas pajak. Hasil pengujian ini tidak dapat mendukung hipotesis 2 yang menyatakan kepemilikan publik berpengaruh negatif terhadap agresivitas pajak, sehingga $\mathrm{H}_{2}$ ditolak.

Hasil penelitian ini tidak dapat mendukung Theory of Planned Behavior yang menjelaskan bahwa perilaku individu terhadap perilaku tertentu diakibatkan oleh niat seorang individu. Niat tersebut muncul dari beberapa faktor, salah satunya yaitu kontrol keperilakuan. Adanya kepentingan pemegang saham dalam perusahaan tampaknya memengaruhi kecendrungan penghindaran pajak 
perusahaan (Core et al., 1999). Proporsi kepemilikan saham publik dapat menimbulkan kontrol yang mempersulit perilaku agresivitas pajak karena pemegang saham publik memiliki kepentingan pada perusahaan sehingga pemegang saham publik akan mengawasi operasi perusahaan agar tidak melakukan hal-hal yang menyimpang dari aturan.

Hasil pengujian ini tidak dapat membuktikan hipotesis 2 yang menyatakan kepemilikan publik berpengaruh negatif terhadap agresivitas pajak. Hasil penelitian ini sesuai dengan penelitian dari Prayogo dan Darsono (2015) yang menyatakan bahwa kepemilikan saham publik tidak berpengaruh terhadap penghindaran pajak. Hal ini disebabkan karena tidak adanya akses langsung dari pemegang saham publik terhadap perusahaan. Pemegang saham publik tidak dapat meningkatkan efektivitas monitoring karena pemegang saham publik tidak memiliki akses langsung terhadap perusahaan, sehingga perusahaan bebas melakukan hal-hal yang menyimpang dari aturan. Tidak adanya pengawasan dari pemegang saham publik menyebabkan tidak adanya pencegahan aktivitas manajemen untuk menurunkan beban pajak perusahaan.

Hipotesis 3 pada penelitian ini yaitu voluntary disclosure dapat memerkuat pengaruh kualitas audit terhadap agresivitas pajak. Hasil yang diperoleh dari uji statistik t pada Tabel 4 menunjukkan bahwa interaksi kualitas audit dan voluntary disclosure $\left(\mathrm{X}_{1} \mathrm{Z}\right)$ memiliki nilai koefisien -0,487 dengan nilai $p$-value sebesar $0,048<0,05$ yang berarti variabel voluntary disclosure mampu memoderasi pengaruh kualitas audit terhadap agresivitas pajak. Nilai koefisien negatif menunjukkan bahwa voluntary disclosure memerlemah pengaruh kualitas audit 
Ni Putu Pradnyawati dan Herkulanus Bambang Suprasto. Pengaruh...

terhadap agresivitas pajak. Artinya, semakin tinggi tingkat voluntary disclosure maka pengaruh kualitas audit terhadap agresivitas pajak akan semakin rendah. Hasil pengujian ini tidak dapat mendukung hipotesis 3 yang menyatakan voluntary disclosure dapat memerkuat pengaruh kualitas audit terhadap agresivitas pajak, sehingga $\mathrm{H}_{3}$ ditolak.

Hasil penelitian ini tidak dapat mendukung teori sinyal yang menjelaskan bagaimana pihak manajemen perusahaan memberikan informasi mengenai keadaan serta prospek perusahaan. Voluntary disclosure yang terdapat pada laporan tahunan bukan merupakan informasi yang bisa digunakan sebagai sinyal dalam mengawasi tindakan agresivitas perusahaan. Hasil penelitian ini tidak dapat membuktikan hipotesis 3 yang menyatakan voluntary disclosure dapat memerkuat pengaruh kualitas audit terhadap agresivitas pajak. Hal ini disebabkan karena voluntary disclosure yang terdapat pada laporan tahunan bukan merupakan informasi yang digunakan auditor untuk mengaudit laporan perusahaan dalam hal pajak.

Hipotesis 4 pada penelitian ini yaitu voluntary disclosure dapat memerkuat pengaruh kepemilikan publik terhadap agresivitas pajak. Hasil yang diperoleh dari uji statistik t pada Tabel 4 menunjukkan bahwa interaksi kepemilikan publik dan voluntary disclosure $\left(\mathrm{X}_{2} \mathrm{Z}\right)$ memiliki nilai koefisien -0,200 dengan nilai $p$-value sebesar 0,819>0,05 yang berarti variabel voluntary disclosure tidak mampu memoderasi pengaruh kepemilikan publik terhadap agresivitas pajak. Artinya, semakin tinggi maupun rendah tingkat voluntary disclosure tidak akan berpengaruh terhadap hubungan kepemilikan publik terhadap agresivitas pajak. 
Hasil pengujian ini tidak dapat mendukung hipotesis 4 yang menyatakan voluntary disclosure dapat memerkuat pengaruh kepemilikan publik terhadap agresivitas pajak, sehingga $\mathrm{H}_{4}$ ditolak.

Hasil penelitian ini tidak mendukung teori sinyal yang menjelaskan bagaimana pihak manajemen perusahaan memberikan informasi mengenai keadaan serta prospek perusahaan. Voluntary disclosure yang terdapat pada laporan tahunan bukan merupakan informasi yang bisa digunakan sebagai sinyal bagi pemegang saham publik dalam mengawasi tindakan agresivitas perusahaan. Pada penelitian ini pemegang saham publik tidak menggunakan voluntary disclosure sebagai sinyal dalam mengawasi tindakan agresivitas pajak perusahaan, sehingga voluntary disclosure tidak dapat memoderasi pengaruh kepemilikan saham publik terhadap agresivitas pajak.

\section{SIMPULAN}

Kualitas audit berpengaruh negatif terhadap agresivitas pajak. Hal tersebut menjelaskan bahwa kualitas audit mampu mengawasi tindakan agresivitas pajak. Semakin baik kualitas audit suatu perusahaan maka tindakan agresivitas pajak akan semakin rendah. Hasil pengujian ini tidak dapat mendukung tiga hipotesis lainnya yang menyatakan kepemilikan publik berpengaruh negatif terhadap agresivitas pajak, voluntary disclosure dapat memerkuat pengaruh kualitas audit terhadap agresivitas pajak, dan voluntary disclosure dapat memerkuat pengaruh kepemilikan publik terhadap agresivitas pajak. 
Ni Putu Pradnyawati dan Herkulanus Bambang Suprasto. Pengaruh...

Bagi penelitian selanjutnya agar dapat mengkaji dan menyempurnakan model penelitian ini, mengingat koefisien determinasi yang tidak terlalu besar, yaitu 10\%. Artinya 90\% dari variasi agresivitas pajak dapat dijelaskan oleh variabel-variabel lain di luar model penelitian. Bagi peneliti selanjutnya diharapkan dapat meneliti variabel lain yang dapat mendeteksi adanya tindakan agresivitas pajak seperti CSR, struktur kepemilikan, karakteristik dewan, leverage, likuiditas, ukuran perusahaan. Dalam penelitian ini pengukuran untuk voluntary disclosure dengan metode checklist memiliki kelemahan subyektifitas peneliti, oleh karena itu untuk peneliti selanjutnya dapat menggunakan metode lain. Pemilihan pengukuran dari agresivitas pajak, kualitas audit, kepemilikan publik, dan voluntary disclosure yang didasarkan pada kajian literatur dan penelitian sebelumnya sehingga pengukuran variabel masih terpaku hanya pada satu macam pengukuran saja.

\section{REFERENSI}

Aguilera, R. V., Desender, K., Bednar, M. K., \& Lee, J. H. (2015). Connecting the Dots: Bringing External Corporate Governance into the Corporate Governance Puzzle. Academy of Management Annals, 9(1), 483-573.

Alviyani, K. (2016). Pengaruh Corporate Governance, Karakterer Eksekutif, Ukuran Perusahaan, dan Leverage terhadap Penghindaran Pajak (Tax Avoidance). JOM Fekon, 3(1), 2540-2554.

Amalia, D. (2005). Faktor-Faktor yang Mempengaruhi Luas Pengungkapan Sukarela (Voluntary Disclosure) pada Laporan Tahunan Perusahaan. Jurnal Akuntansi Pemerintah, 1(2), 1-17.

Annisa, N. A., \& Kurniasih, L. (2012). Pengaruh Corporate Governance terhadap Tax Avoidance. Jurnal Akuntansi \& Auditing, 8(2), 123-136. 
Atiah, U., Ethika, \& Minovia, A. F. (2016). Pengaruh Kompensasi Eksekutif, Leverage, Struktur Kepemilikan, dan Komisaris Independen terhadap Penghindaran Pajak. Journal of Financial Economics, 9(1), 1-14.

Core, J. E., Holthausen, R. W., \& Larcker, D. F. (1999). Corporate Governance, Chief Executive Officer Compensation, and Firm Performance. Journal of Financial Economics, 51(3), 371-406.

DeAngelo, L. E. (1981). Auditor Independence, "Low Balling", and Disclosure Regulation. Journal of Accounting and Economics, 3(2), 113-127.

Dewi, N. L. P. P., \& Noviari, N. (2017). Pengaruh Ukuran Perusahaan, Leverage, Profitabilitas dan Corporate Social Responsibility terhadap Penghindaran Pajak (Tax Avoidance). E-Jurnal Akuntansi Universitas Udayanaa, 21(1), 830-859.

Dewi, N. N., \& Jati, I. K. (2014). Pengaruh Karakter Eksekutif, Karakteristik Perusahaan, dan Dimensi Tata Kelola Perusahaan yang Baik pada Tax Avoidance di Bursa Efek Indonesia. E-Jurnal Akuntansi Universitas Udayana, 6(2), 249-260.

Dyreng, S. D., Hanlon, M., \& Maydew, E. L. (2008). Long- Run Corporate Tax Avoidance. The Accounting Review, 83(1), 61-82.

Eksandy, A. (2014). Pengaruh Komisaris Independen, Komite Audit dan Kualitas Audit terhadap Penghindaran Pajak (Tax Avoidance). Competitive, 1(1), 120 .

Frank, M. M., Lynch, L. J., \& Rego, S. O. (2009). Tax Reporting Aggressiveness and Its Relation to Aggressive Financial Reporting. In Accounting Review, 84(2), 467-496.

Friese, A., Link, S. P., \& Mayer, S. (2006). Taxation and Corporate Governance. SSRN.

Healy, P. M., \& Palepu, K. G. (1993). The Effects of Firms Financial Disclosure Strategies on Stock Prices. Accounting Horizons, 7(1), 1-11.

Hidayati, N., \& Fidiana. (2017). Pengaruh Corporate Social Responsibility dan Good Corporate Governance terhadap Penghindaran Pajak. Jurnal Ilmu dan Riset Akuntansi, 6(3), 1052-1070.

Hite, Peggy A., dan McGill, G. (1992). An Examination of Taxpayer Preferences for Agresive Tax Advice.National Tax Journal, 45, hal.389-403. 
Hoi, Chun-Keung, Qiang Wu, \& Hao Zhang. (2013). Is Corporate Social Responsinility (CSR) Assosiated with Tax Avoidanve? Evidence from Irresponsible CSR Activities. The Accounting Review, 88(6), 2025-2059.

Indrawan, Y. (2016). Pengaruh Good Corporate Governance dan Koneksi Politik terhadap Penghindaran Pajak pada Perusahaan BUMN yang Terdaftar di Bursa Efek Indonesia (BEI) Tahun 2010-2014. Skripsi Universitas Airlangga, Surabaya.

Jesen, M. C., W. H. Meckling. (1976). Theory of The Firm : Manajerial Behaviour, Agency Cost, and Ownership Structure. Journal of Financial and Economics, 3(4), hal. 305-360.

Maharani, I. G. A. C., \& Suardana, K. A. (2014). Pengaruh Corporate Governance, Profitabilitas dan Karakteristik Eksekutif pada Tax Avoidance Perusahaan Manufaktur. E-Jurnal Akuntansi Universitas Udayana, 2(2), $525-539$.

Mangoting \& Hadi. (2014). Pengaruh Struktur Kepemilikan dan Karakteristik Dewan terhadap Agresivitas Pajak. Tax and Accounting Review, 4(2), 1-10.

Meek, G. K., Roberts, C. B., \& Gray, S. J. (1995). Factors Influencing Voluntary Annual Report Disclosures By U.S., U.K. and Continental European Multinational Corporations. Journal of International Business Studies, 555572.

Minnick, K., \& Noga, T. (2010). Do corporate governance characteristics influence tax management? Journal of Corporate Finance, 16(5), 703-718.

Oktaviana, L. L. (2017). Pengaruh Kepemilikan Saham dan Corporate Social Responsibility terhadap Agresivitas Pajak. Jurnal Ilmu Dan Riset Akuntansi, 6(11), 1-20.

Partha, I. G. A., \& Noviari, N. (2016). Pengaruh Penghindaran Pajak Jangka Panjang pada Nilai Perusahaan dengan Transparansi Informasi sebagai Variabel Pemoderasi. E-Jurnal Akuntansi Universitas Udayana, 14(3), 2336-2362.

Prayogo, K. H., \& Darsono. (2015). Faktor-Faktor yang Berpengaruh terhadap Penghindaran Pajak Perusahaan. Diponegoro Journal of Accounting, 4(3), 112.

Puspita, S. R., \& Harto, P. (2014). Pengaruh Tata Kelola Perusahaan terhadap Penghindaran Pajak. Diponegoro Journal Of Accounting, 3(2), 1-13.

Rosnidah, I. (2010). Kualitas Audit Refleksi Hasil Penelitian Empiris. Jurnal 
Akuntansi, 14(9), 329-336.

Santoso, T. B., \& Muid, D. (2014). Pengaruh Corporate Governance terhadap Penghindaran Pajak Perusahaan. Diponegoro Journal Of Accounting, 3(4), $1-12$.

Sehar, N., \& Tufail, S. (2013). Determinants of Voluntary Disclosure in Annual Report: A Case Study of Pakistan. Management and Administrative Sciences Review.

Slemrod, J. (2004). The Economics of Corporate Tax Selfishness. National Tax Journal.

Suprimarini, N. P. D., \& Suprasto, B. (2017). Pengaruh Corporate Social Responsibility, Kualitas Audit, dan Kepemilikan Institusional Pada Agresivitas Pajak. E-Jurnal Akuntansi Universitas Udayana, 19(2), 13491377.

Sutedi, A. (2012). Good Corporate Governance. Jakarta: Sinar Grafika.

Vander Bauwhede, H., Willekens, M., \& Gaeremynck, A. (2003). Audit firm size, public ownership, and firms' discretionary accruals management. International Journal of Accounting.

Winata, F. (2014). Pengaruh Corporate Governance terhadap Tax Avoidance pada Perusahaan yang Terdaftar di Bursa Efek Indonesia Tahun 2013. Tax \& Accounting Review, 4(1), 1-11.

Wulandari, Y., \& Laksito, H. (2015). Analisis Faktor-Faktor yang Mempengaruhi Luas Pengungkapan Sukarela pada Laporan Keuangan Tahunan. Diponegoro Journal Of Accounting, 4(3), 1-9. 